COMMENTARY ON COVID-19 AND THE FoOd SYSTEM

\title{
COVID-19 containment and food security in the Global South
}

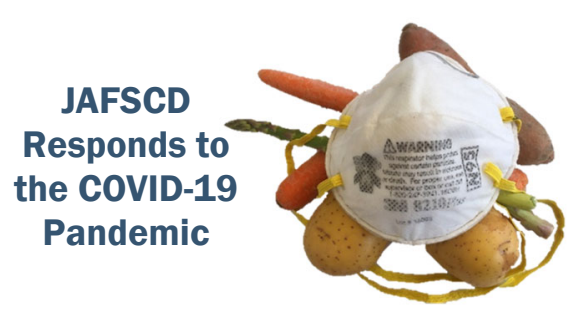

Jonathan Crush a and Zhenzhong $\mathrm{Si}^{\mathrm{b}}$ *

Wilfrid Laurier University

Submitted July 10, 2020 / Published online July 27, 2020

Citation: Crush, J., \& Si, Z. (2020). COVID-19 containment and food security in the Global South. Journal of Agriculture, Food Systems, and Community Development, 9(4), 149-151. https://doi.org/10.5304/jafscd.2020.094.026

Copyright (C 2020 by the Authors. Published by the Lyson Center for Civic Agriculture and Food Systems. Open access under CC-BY license

\begin{abstract}
Population-level COVID-19 containment strategies have been particularly hard on the urban poor and vulnerable population groups such as female-headed households, children, youth, the homeless, informal sector employers and employees, casual workers, the unemployed, and migrants and refugees. As a direct result of the COVID-19 outbreak, a secondary pandemic of hunger and food insecurity is now impacting many of these groups. An effective and sustainable global response to the COVID-19 (and any further) viral pandemics must ensure that food security is an essential piece of the containment and mitigation puzzle.
\end{abstract}

\section{Keywords}

Food Security, Food Security Policy, COVID-19, Pandemic, China, Global South

A primary indirect consequence of the growing COVID-19 pandemic across the Global South is a dramatic increase in the prevalence of hunger and food insecurity (HLPE, 2020). The Food and Agriculture Organization of the United Nations (FAO) (2020) has called the food security consequences a crisis

a Jonathan Crush, Professor, Wilfrid Laurier University, jcrush@wlu.ca

b * Corresponding author: Zhenzhong Si, Postdoctoral Fellow, Wilfrid Laurier University; 307 Balsillie School of International Affairs; 67 Erb Street W; Waterloo, ON N2L 6C2, Canada; sizhenzhong@gmail.com

\section{Funding Disclosure}

The research was supported by the COVID-19 Rapid Research Grant funded by the New Frontiers in Research Fund. 
within a crisis, while the World Food Program calls it a hunger pandemic, warning that 30 million people could die of starvation during the pandemic (Husain, Sandström, Greb, Groder, \& Pallanch, 2020). The number of severely food insecure people could more than double, from 130 million to 265 million, by the end of 2020. The disruption to food systems has important implications for epidemic control and the current and future food security of urban residents. Impaired food security may increase susceptibility to infection and worsen the well-being of the infected (HLPE, 2020). The interconnections between food insecurity and the outbreak highlight the urgent need to examine and improve food security interventions, both during and in the aftermath of the pandemic (Husain et al., 2020).

The dramatic increase in urban food insecurity is partly a function of the disruptions in national and globalized food supply chains (Clapp, 2020). Food access is highly contingent on the importation of food from the hinterland or global markets. While food production, distribution, and retailing are generally considered 'essential services,' many states have allowed formal retailers, such as supermarkets and their supply chains, to remain operational while shutting down the informal food sector on which the urban poor depend. In addition, restrictions on internal movement and international travel have negatively affected informal cross-border trade in foodstuffs.

Governments in the Global South have responded to COVID-19 with a range of containment, economic, and public health strategies. The Oxford Coronavirus Government Tracker (OxCGRT) identifies 18 separate government measures (Table 1). We have added another eight common measures observed in the Global South to the OxCGRT list. As Hale et al. (2020) note, government responses to COVID-19 within each category exhibit "significant nuance and heterogeneity," and their impact is "highly contingent" on local political and social contexts (Hale et al., 2020). For example, $\mathrm{C} 7$ measures range from complete residential

\section{Table 1. Government Responses to CoVID-19}

\begin{tabular}{ll}
\hline No. & Name \\
\hline Containment and closure measures \\
\hline C1 & Behavior change (social distancing, mask-wearing, hand-washing) \\
\hline C2 & School closing \\
\hline C3 & Workplace closing \\
\hline C4 & Cancel public events \\
\hline C5 & Restrictions of gathering size \\
\hline C6 & Close public transport \\
\hline C7 & Stay at home requirements (including lockdowns, quarantine, curfews) \\
\hline C8 & Restrictions on internal movement \\
\hline C9 & Restrictions on international travel \\
\hline C10 a & Closure of public spaces (parks, beaches, etc.) \\
\hline C11 ${ }^{\text {a }}$ & Closing food markets (wholesale, retail, informal, wet) \\
\hline C12 ${ }^{\text {a }}$ & Banning informal sector vending \\
\hline C13 ${ }^{\text {a }}$ & Banning sales of alcohol, cigarettes \\
\hline Economic measures \\
\hline E1 & Income support \\
\hline E2 & Debt/contract relief for households \\
\hline E3 & Fiscal measures \\
\hline E4 & Giving international support \\
\hline E5 a ${ }^{\text {a }}$ & Social grant support \\
\hline E6 ${ }^{\text {a }}$ & Food distribution \\
\hline Public health measures \\
\hline $\mathrm{H} 1$ & Public information campaign \\
\hline H4 & Testing policy \\
\hline
\end{tabular}


lockdowns, as in Chinese cities and migrant worker hostels in Qatar and Singapore, to general appeals by politicians about hand washing and social distancing (Crush, 2020).

Contextual variables include the ability of lower-tier governments (state, municipal) to comply with national policies; the degree and type of enforcement; and the response of people themselves to measures that restrict their mobility, income, recreation, and social life. Some countries, such as South Africa, have deployed the army to enforce containment. Further complicating the picture, each measure is dynamic rather than static, and subject to change, modification, and partial or wholesale relaxation. While some countries, such as China, continued with these policies until the coronavirus was under control, others have opted to loosen restrictions due to the severe economic toll of COVID-19. Further waves of infection are widely anticipated in these jurisdictions.

Containment measures have had an immediate impact on food security in many Southern cities, through the disruption of food supply chains, partial or complete bans on informal food markets and street vending, controls on movement, layoffs, and unemployment, a precipitous decline in household income, and the shuttering of school feeding programs. Most poor urban households live in conditions where individual social distancing measures are impossible to implement. Particularly vulnerable are the urban poor in low-income and informal settlements and, within these areas, population subgroups such as female-headed households, older adults, day laborers, workers in the informal sector, the homeless, and migrants and refugees. Hunger is driving desperate people to defy containment measures and turn to causing social unrest, including looting of food outlets and delivery trucks. Some governments have introduced or ramped up existing social protection and food distribution programs, while others have focused on ensuring compliance through force.

The Hungry Cities Partnership (HCP) focuses its attention on the transformation of food systems accompanying rapid urbanization and the vulnerability of urbanizing populations to food insecurity. In early 2020, HCP began a project on the food-security consequences of the COVID-19 pandemic in China. We are now upscaling this research to six additional sites in Africa and Latin America. We will be exploring how containment responses to COVID-19 have impacted urban populations in six cities with a combined population of over 20 million people. In scaling up this research, we are focusing on cities and populations with low levels of pre-COVID food security to discern whether public health policy responses have exacerbated food insecurity and, if so, in what ways.

\section{References}

Clapp, J. (2020, May 8). Spoiled milk, rotten vegetables and a very broken food system. The New York Times. https://www.nytimes.com/2020/05/08/opinion/coronavirus-global-food-supply.html

Crush, J. (2020, April 8). COVID-19 lockdowns and the global migration regime. Retrieved from the Hungry Cities Partnership website: https://hungrycities.net/covid-19-lockdowns-global-migration-regime/

Food and Agriculture Organization of the United Nations (FAO). (2020). COVID-19: Our hungriest, most vulnerable communities face 'a crisis within a crisis.' Retrieved from http://www.fao.org/news/story/en/item/1269721/icode/

Hale, T., Angrist, N., Kira, B., Petherick, A., Phillips, T., \& Webster, S. (2020). Variation in government responses to COVID19 version 6.0. Working Paper, Blavatnik School of Government, University of Oxford. http://www.bsg.ox.ac.uk/covidtracker

High-Level Panel of Experts on Food Security and Nutrition [HLPE]. (2020, March). Interim issues paper on the impact of COVID-19 on food security and nutrition. Retrieved from the Committee on World Food Security website: http://www.fao.org/cfs/cfs-hlpe/en/

Husain, A., Sandström, S., Greb, F., Groder, J., \& Pallanch, C. (2020, April 8). COVID-19: Potential impact on the world's poorest people. Retrieved from the World Food Program website: https://www.wfp.org/publications/covid-19-potential-impact-worlds-poorest-people 